\title{
Sustainable Water Supply Model in Ambon Island
}

\author{
Jumsy D. Putuhena \\ Pattimura University, Campus Poka Ambon, Indonesia
}

Asep Sapei

Bogor Agricultural Institute, Bogor Darmaga Campus, Indonesia

M. Yanuar J. Purwanto

Bogor Agricultural Institute, Bogor Darmaga Campus, Indonesia

Liliek B. Prasety

Bogor Agricultural Institute, Bogor Darmaga Campus, Indonesia

Received: October 7, 2014 Accepted: November 6, 2014 Published: December 31, 2014

doi:10.5296/jee.v5i2.6893 URL: http://dx.doi.org/10.5296/jee.v5i2.6893

\begin{abstract}
Land-use changes from forest to other use will affect watershed hydrological system that lead to water availability in Leitimur Peninsula watershed, Ambon Island. It aims to analyze sustainability index and sensitive attribute of watershed management and to design watershed management model in supporting sustainability of water resources in Leitimur Peninsula. The analysis applies the Multidimensional Scaling (MDS) model and the dynamic model (Stella). The findings signifies that multidimensional sustainability status is $50.97 \%$ indicating quite sustainable, while the best management model is by performing land and forest rehabilitation (LFR) and agricultural extensification through agro-forestry system.
\end{abstract}

Keywords: Watershed management 


\section{Introduction}

\subsection{Background of the Study}

Critical watershed phenomena in Indonesia becomes a quite serious environmental issues. It is noted in 1984 that 22 watershed was critical, then in 1992, the number was increasing to 39 watershed, to 42 watershed in 1998, to 59 watershed in 2000, and last, it was 60 watershed was critical in 2002 (Kartodihardo and Jhamtani, 2006). In 2005, the number or critical watershed in Indonesia was 62, and it was increasing up to 291 critical watershed in 2008 (Multilaksono, 2009).

Presence of forest can prevent tremendous flood and drought. The explanation above disclose the importance of land management along with the vegetation for water availability in watershed (Asdak, 2007). Tumuhury (2003) states that in Brantas watershed, imbalance of water occurs as the consequence of land cover which changes into non-vegetation area. Likewise, Li, et al. (2006) states that central China's mega city has faced land use changes into residential area from $9.1 \%$ in 1987 to $29.6 \%$ in 1999. This change has decreased water count from $30.4 \%$ to $23.8 \%$. Forest area has also decreased from $33.6 \%$ to $24.3 \%$.

Defra (2004) states that effective land management can prevent water resources damages. This statement is affirmed by Wheater (2009) that longterm management to prevent flood is performed by balancing the land use, economic development and harmonious environmental utilization.

Ambon City is located in small island (Ambon Island) where population growth is quite high at population increase rate by $3.43 \%$ from the previous year in 2007. Population of Ambon City in 2008 was 281,293. Population density in Ambon City in 2007 was 757 per Km², and it was increasing to 783 per $\mathrm{Km}^{2}$ in 2008 (Central Bureau of Statistics of Ambon City, 2008).

Batu Merah watershed in Ambon City is one of critical watershed locations in Indonesia (Nugroho, 2003 in Kartodiharjo and Jhamtani, 2006). Land use in Ambon City today is dominated by residential area and other supporting infrastructure such as roads, religious facilities, schools and so forth. This condition was driven by population growth and social conflict that impel watershed hydrological system damage; consequently, it makes critical land, erosion and sedimentation, flood in rainy season and drought in dry season often.

Residents of Leitimur Peninsula in Ambon City utilize clean water from five watershed, i.e. Batu Gantung watershed, Batu Gajah watershed, Wai Tomu watershed, Batu Merah watershed and Wae Ruhu watershed. Remaining residents utilize water well. Condition of watershed in Ambon City are critical, including these five watershed.

\subsection{Research Objectives}

Main objective of the study is to design watershed management model in an effort to maintain water resources sustainability. For details, the following are research objectives:

1. To analyze sustainability index and sensitive attribute of watershed management in Leitimur Peninsula. 


\section{Macrothink}

2. To design watershed management model in maintaining water resources sustainability ecologically, economically and socially in Leitimur Peninsula.

\section{Research Methodology}

\subsection{Research Sites}

Physically, the study is conducted in Batugantung watershed, Batu Gajah watershed, Wai Tomu watershed, Batu Merah watershed and Ruhu watershed in Leitimur Peninsula, Ambon Island (Figure 1). Limitations determined in this study is an area surrounding the watershed which become the water resource area to supply drinking water in Ambon City of 4,123.09 ha.

\subsection{Data Sampling}

Primary data is land biophysical data from National Land Affairs Body of Ambon City, characteristics of the watershed and condition of land cover obtained from field survey, interview with expert respondents by questionnaire. Secondary data are climate data from the Indonesian Agency for Meteorological, Climatological and Geophysics, Pattimura Airport, Ambon, Landsat 7 Image from National Space/Austronautical Flight Agency and discharge of river from Public Works Department of Ambon Province and River Research Center of Maluku Province. 
2.3 Research Design

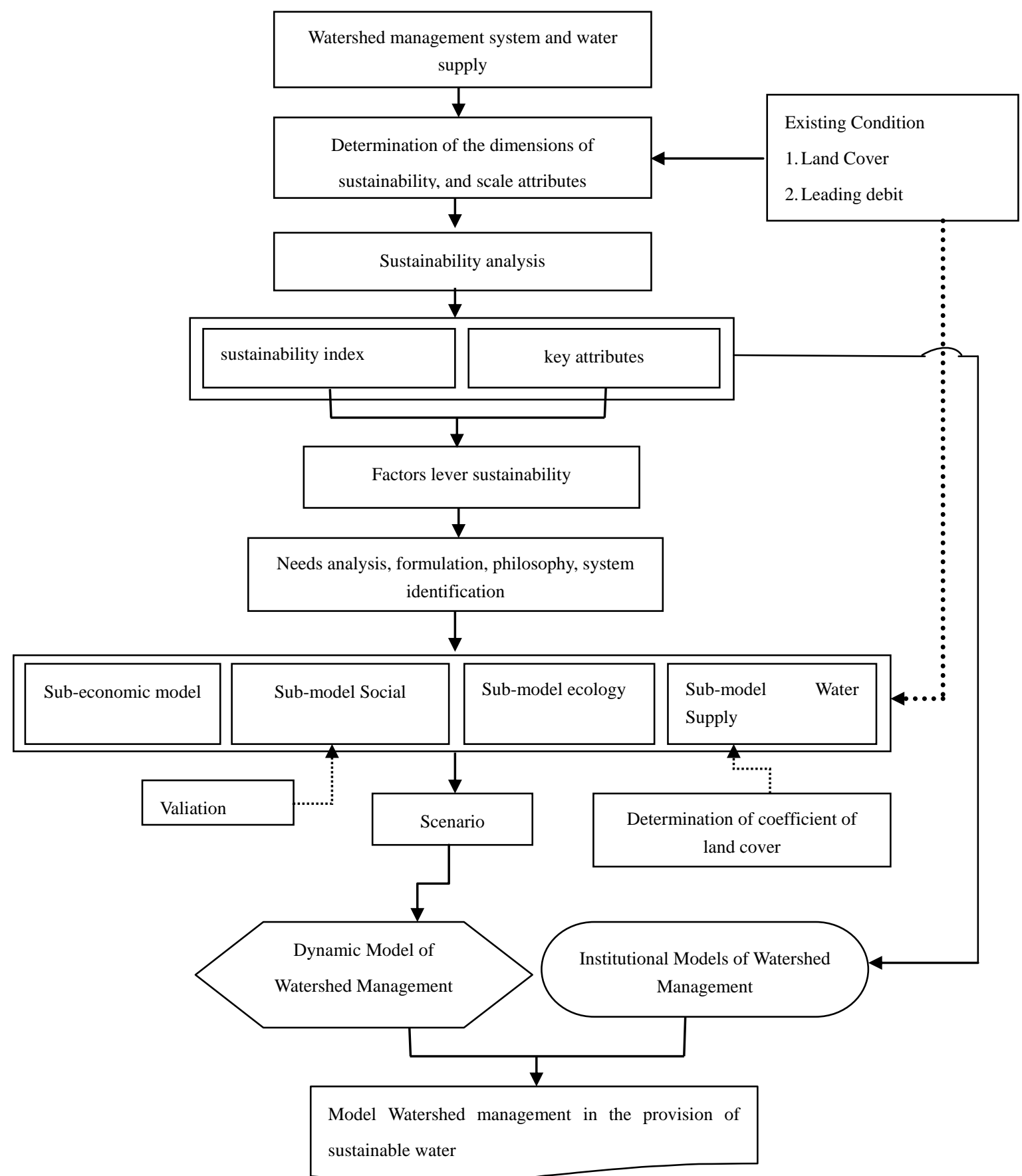

Figure 1. Research design scheme

\subsection{Model Design of Watershed Management Sustainability Analysis in Leitimur Peninsula}

Watershed management sustainability analysis in Leitimur Peninsula is performed by Multi Dimensional Scaling (MDS) method. The analysis is performed in some steps as follows:

Determination of attribute and sustainability for watershed management covers three dimensions, they are ecological, economic and social dimensions. 


\section{Macrothink}

Assessment of every attribute at ordinal scale is based on sustainable criteria of every dimension.

Calculation on index, then, is performed and followed by analyzing sustainability status.

Afterward, score of every attribute is analyzed by using multi dimensional to determine if a point reflect status of watershed management sustainability in Ambon City. The point is sustainable relative position which will be examined toward two reference points, i.e. good and bad point.

Table 1. Category for watershed management sustainability status in Leitimur Peninsula

\begin{tabular}{cc}
\hline Index Score & Category \\
\hline $0.00-25.00$ & Bad (unsustainable) \\
$25.01-50.00$ & Minus (less sustainable) \\
$50.01-75.00$ & Moderate (quite sustainable) \\
$75.01-100.00$ & Good (very sustainable) \\
\hline
\end{tabular}

Source: Fauzi and Anna (2005).

By having MDS method, position of sustainability point can be illustrated in kite diagram as seen in Figure 2 below:

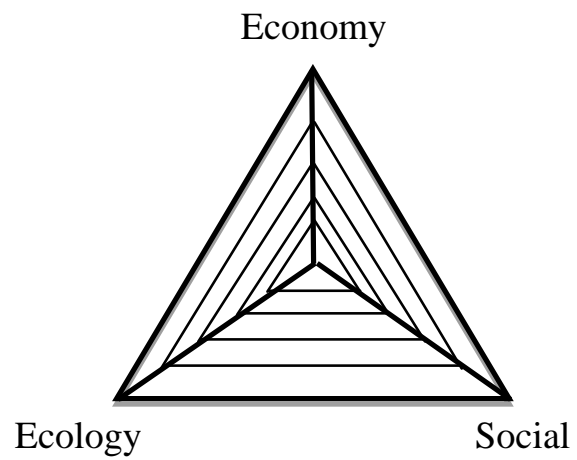

Figure 2. Illustration of multi dimensional sustainability index

\section{Findings and Discussion}

\subsection{The Conditions of Existence}

a. Land Cover

Outcome of overall accuracy score is $83.56 \%$, and it is detailed in the Table 2 below:

Table 2. The width of each land cover in five watershed, Ambon City

\begin{tabular}{|c|c|c|c|c|c|c|}
\hline \multirow{2}{*}{ No. } & \multirow{2}{*}{ Land Use/Land Cover } & \multicolumn{2}{|c|}{2002} & \multicolumn{2}{|c|}{2009} & \multirow{2}{*}{$\begin{array}{c}\text { Changes } \\
\text { (ha) }\end{array}$} \\
\hline & & $\mathrm{Ha}$ & $\%$ & $\mathrm{Ha}$ & $\%$ & \\
\hline 1 & Secondary Forest & 918.96 & 22.29 & $1,664.68$ & 40.37 & +745.2 \\
\hline 2 & $\begin{array}{l}\text { Dryland } \\
\text { Farming }\end{array}$ & $1,680.94$ & 40.77 & 310.99 & 7.54 & $-1,369.95$ \\
\hline
\end{tabular}




\begin{tabular}{llrrrrr}
3 & Open Field & 42.31 & 1.03 & 66.60 & 1.62 & +24.29 \\
4 & Residential Area & 479.06 & 11.62 & 498.12 & 12.08 & +19.06 \\
5 & Dryland Farming & 979.60 & 23.76 & 141.45 & 3.43 & -838.15 \\
6 & Brushwood & 22.23 & 0.54 & $1,441.27$ & 34.96 & $-1,419.04$ \\
\hline \multicolumn{2}{c}{ Total } & $4,123.1$ & 100.01 & $4,123.11$ & 100 & -0.01 \\
\hline
\end{tabular}

Information: (+) area expansion, (-) area reduction

b. Hydrological Characteristics and Dependable Discharge

The changes of land use into urban development is unpreventable phenomenon from deforestation to impermeable layer in form of residential roof, roads, parking lot, airport, and so forth. Visible effect of the changes has increased flood intensity and frequency. This changes is faced watershed in Ambon City too, including Wai Ruhu watershed, Batu Merah watershed, Wai Tomu watershed, Batu Gajah watershed, and Batugantung watershed. The five watershed are changing rapidly that automatically affect the response of watershed hydrological.

Characteristics of the watershed in Ambon City analyzed in this study include thw width of watershed, number of sub-watershed, length of and form of watershed and discharge as detailed in the Table 3 below.

Table 3. Watershed hydrological characteristics in Ambon City

\begin{tabular}{llrrrr}
\hline No. & Watershed & $\begin{array}{c}\text { Area of } \\
\text { Watershed } \\
\text { (ha) }\end{array}$ & $\begin{array}{c}\text { Number of } \\
\text { sub-watershed }\end{array}$ & $\begin{array}{c}\text { River } \\
\text { length } \\
(\mathrm{km})\end{array}$ & $\begin{array}{c}\text { Type of } \\
\text { watershed }\end{array}$ \\
\hline 1. & Wai Ruhu & $1,524.97$ & 55 & 11.8 & Lengthen \\
2. & Batu Merah & 578.13 & 21 & 6.8 & Broaden \\
3. & Wai Tomu & 414.49 & 13 & 6.2 & Lengthen \\
4. & Batu Gajah & 550.53 & 19 & 6.6 & Lengthen \\
5. & Batu Gantung & 865.07 & 33 & 5.6 & Broaden \\
\hline
\end{tabular}

Dependable discharge obtained based on RAINBOW simulation outcome for $80 \%$ opportunity is $0.2820 \mathrm{~m}^{3} / \mathrm{sec}$ in Wau Ruhu; $0.1528 \mathrm{~m}^{3} / \mathrm{sec}$ in Batu Merah river; $0.2581 \mathrm{~m}^{3} / \mathrm{sec}$ in Wai Tomu; $0.1323 \mathrm{~m}^{3} / \mathrm{sec}$ in Batu Gajah river; $0.2209 \mathrm{~m}^{3} / \mathrm{sec}$ in Batu Gantung. Total water availability from the five watershed are $106,720,977.60 \mathrm{~m}^{3}$ in Wai Ruhu, $57,824,409.60 \mathrm{~m}^{3}$ in Batu Merah river, 97,685,913.60 $\mathrm{m}^{3}$ in Wai Tomu, 50,069,707.20 $\mathrm{m}^{3}$ in Batu Gajah river and $83,579,860.80 \mathrm{~m}^{3}$ in Batu Gantung; thus, total water availability in the rivers is $395,880,868.80 \mathrm{~m}^{3}$.

\section{c. Water Needs Analysis}

The size of water consumption can trigger various types of published standards. Domestic water needs standards is based on criteria of population and type of the city in conformity with Guidance for Construction and Building, Dept. of Public Works. Regarding the number of population in Ambon City, it is considered as Moderate city with amount of water needs of 
90-100 liters/person/day. If population is 331,254 people in 2010, the average domestic water needs is 100 liters/person/day (Water Needs Standards for Various Sectors, Indonesian National Standards 19-6728,1-2002). Therefore, water needs in Ambon City in 2010 is found out as presented in the Table below.

Table 4. Water Needs, Production and Availability in Ambon City in 2010

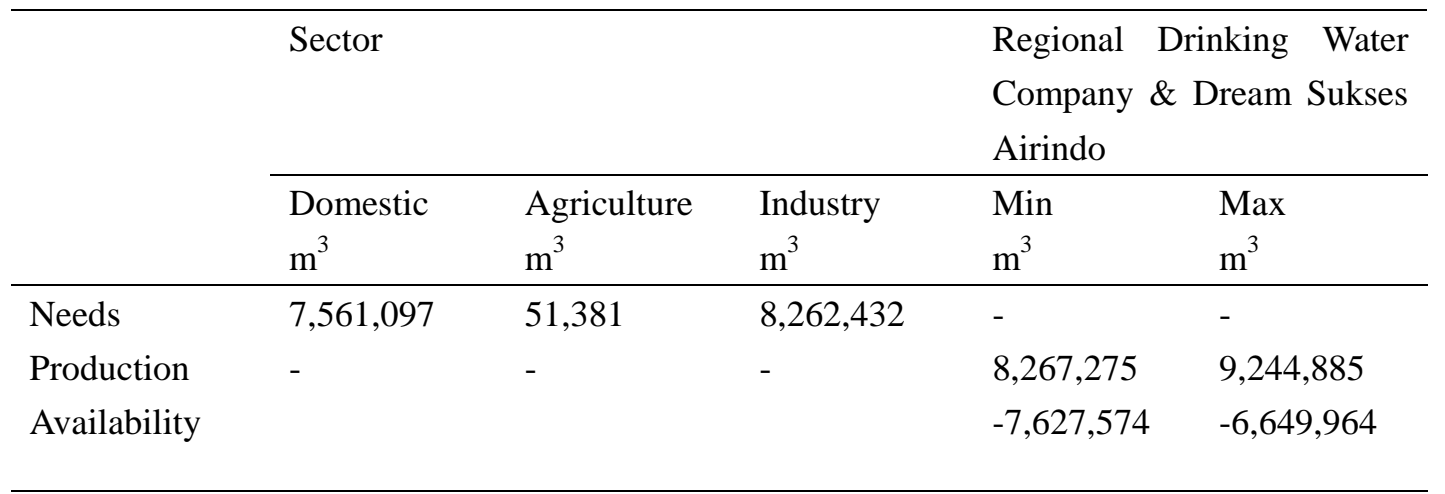

Information: total water availability is $15,894,849 \mathrm{~m}^{3}$

Overall water needs in research sites are for domestic, animal husbandry, and industry by $15,894,849 \mathrm{~m}^{3}$ in 2010 .

If water production is calculated based on the water needs in research sites where the sites are the Ambon downtown, the production will not enough for the size of $15,894,849 \mathrm{~m}^{3}$ in 2010 . Water production supplied for community at minimum supply during dry season reaches $8,267,275 \mathrm{~m}^{3}$ and $9,244,885 \mathrm{~m}^{3}$ during rainy season, or water is supplied by Regional Drinking Water Company as drinking water supplier which only supplies $52.01 \%$ only. The remaining water which has not been fulfilled is $7,627,574 \mathrm{~m}^{3}(47.98 \%)$ in dry season, while water needs of the community in rainy season is $48.51 \%\left(8,148,297 \mathrm{~m}^{3}\right)$.

\subsection{Watershed Sustainability Status in Ambon City}

a. Sustainability Index

Analysis result through Rap-Insus of Ambon City watershed found sustainability index score for every dimension as follows:

- Ecological dimension at $38.55 \%$ indicates less sustainable (when the index ranges between 25.00 to $49.99 \%$ ).

- Economic dimension at 56.28\% indicates quite sustainable (when the index ranges between 50.00 to $74.99 \%$ ).

- Social dimension at $60.15 \%$ indicates quite sustainable (when the index ranges between 50.00 to $74.99 \%$ ).

Analysis result of Rap-Insus for Ambon City watershed is presented in the Figure 3 below: 


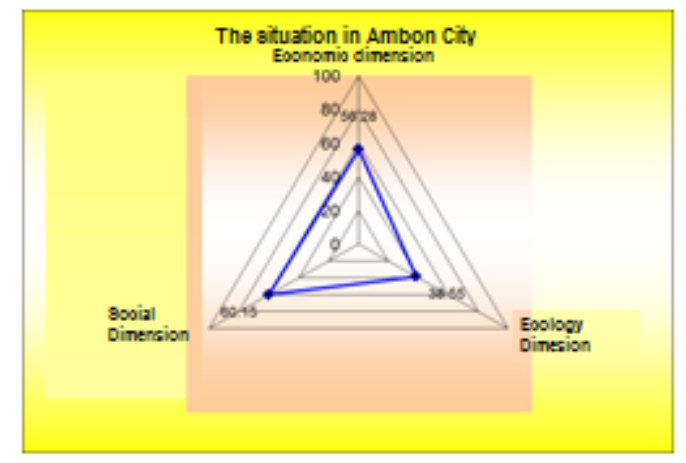

Figure 3. Watershed Sustainability Status in Ambon City

According to some involved experts, they state that weighted quality of every dimension found $38.55 \%$ for ecological dimension, $56.28 \%$ for economic dimension and $60.15 \%$ for social dimension. Based on weighting of the three economic, ecological and social dimensions, sustainability index score is $50.97 \%$ (which ranges between $50.00 \%$ to $74.99 \%$ ) indicating quite sustainable. This sustainability index score at $50.97 \%$ means a quite sustainable, but it still is in a vulnerable position which tend to be unsustainable status. Consequently, this sustainable status is vulnerable since it is just $0.50 \%$ above the lower bound.

\section{b. Leverage Factor}

There are 13 leverage factors which the change can affect sensitively sustainability rate index escalation of the three dimensions. These 13 dimensions are divided into 5 factors in ecological dimension, 4 factors in economic dimension, and 4 factors in social dimension. Performance of these 13 factors can be improved or maintained to make them stable in increasing watershed sustainability index in Ambon City. The leverage factors are presented in Table 5 below.

Table 5. Leverage factors per dimensions of watershed sustainability in Ambon City

\begin{tabular}{|c|c|c|c|}
\hline No. & Dimension & Leverage Factor & RMS \\
\hline \multirow[t]{5}{*}{1} & Ecology (5) & 1. River Stream Discharge (KRS) & 5.00 \\
\hline & & 2. Water use index (IPA) & 4.29 \\
\hline & & 3. Vegetation index (IPL) & 3.33 \\
\hline & & 4. Conservative agricultural pattern & 3.21 \\
\hline & & 5. Forest area adequacy & 2.95 \\
\hline \multirow[t]{5}{*}{2} & Economy (4) & 6. Employment at Agroforestry & 5.09 \\
\hline & & 7. Consumer dependency to agroforestry product. & \\
\hline & & & 2.88 \\
\hline & & 8. Potential for tourism. & 2.88 \\
\hline & & 9. Farmer income from agroforestry. & 2.82 \\
\hline 3 & Social (5) & 10. Community dependency to the watershed. & 4.61 \\
\hline
\end{tabular}


11. Community participation rate.

12. Land-use conflict

13. Rules of local institution

2.90

\subsection{Cenarion Projection for Watershed Management}

a. Watershed Management and Water Discharge as the Limiters

Water discharge is highly affected by rainfall, slope, type of land cover and soil type. In existence condition, when the forest tends to raise, dryland farming and dryland mixed farming decrease and change to residential area and brushwood. This condition is definitely unfavorable economically since the forest in Ambon City is set as protection forest with no timber product whereas, dryland farming and dryland mixed farming in the brushwood is not managed continuously. Therefore, to escalate surface runoff absorption (discharge) in this simulation, ecological and economic aspects in community shall be taken into consideration.

The built up scenario is made by considering that ecological aspect will be better if economic aspect becomes a part of consideration in watershed management. Scenario models offered in this study are presented in Table 6 below.

Scenario 1: extensification of farming through agroforestry; it is land cropping beyond forest area by combining plants of mahogany, clove, avocado and other annual crop such as vegetables and herb garden. Scenario 2: land and forest rehabilitation and extensification of farming through agroforestry; it is planting conducted in and beyond the forest area either by land and forest rehabilitation pattern, or farm land expansion by agroforestry pattern. Scenario of land and forest rehabilitation is forest planting that utilizes forest crop in various activities in land and forest rehabilitation.

\section{b. Land-use Changes}

If the simple scenario is only performed by land and forest rehabilitation, the width of the forest will be more extensive up to a portion of forest area to $40 \%$ total area of watershed. If extensification of farming with agroforestry pattern is performed, the width of dryland farming will be wider, but dryland mixed farming will increase in 2043. Other trend indicated by declining brushwood area which afterwards it becomes low land until 2043 is brushwood area narrowing as the consequence of land conversion into dryland mixed farming. This area narrowing is driven by extensification in farming conducted in stages for 10 years.

In Complex scenario, forest area is expanding up to 1600 ha, while dryland farming area is increasing above forest area expansion up to 1700 ha. The width of the dryland mixed farming in 2043 reaches 100 ha whereas the width of brushwood is decreasing less than 200 ha. Slow area expansion of dryland mixed farming is triggered by community will to increase the width of short-lived farming. If all scenarios are put in a table, those differences are seen in Figure 4 below. 


\section{Macrothink}

Table 6. Scenario of dynamic model implementation for watershed management in Ambon City

\begin{tabular}{|c|c|c|}
\hline $\begin{array}{c}\text { Consideration for } \\
\text { Watershed Improvement }\end{array}$ & Scenario & Explanation \\
\hline \multirow[t]{3}{*}{$\begin{array}{l}\text { 1. River stream } \\
\text { discharge. } \\
\text { 2. Water use index. } \\
\text { 3. Forest land cover } \\
\text { sufficiency }(40 \%) \\
\text { 4. Farmer income from } \\
\text { agroforestry }\end{array}$} & $\begin{array}{c}\text { I } \\
\text { Simple } \\
\text { (Pessimist) }\end{array}$ & $\begin{array}{l}\text { 1. Extensification of agricultural land through } \\
\text { agroforestry in brushwood area } \\
\text { 2. Population growth by } 2.00 \% \text {. } \\
\text { 3. Leakage control by } 10 \% \text { (the first five year by } \\
5 \% \text {, and the following } 10 \text { years by } 5 \% \text { ). } \\
\text { 4. Additional production of Regional Drinking } \\
\text { Water Company by } 10 \% \text { in the seventh year. }\end{array}$ \\
\hline & $\begin{array}{c}\text { II } \\
\text { (Moderate) }\end{array}$ & $\begin{array}{l}\text { 1. Combination between land and forest } \\
\text { rehabilitation and extensification of agricultural } \\
\text { farming through agroforestry. } \\
\text { 2. Population growth by } 2.00 \% \text {. } \\
\text { 3. Leakage control by } 15 \% \text { (the first five year by } \\
5 \% \text {, and the following } 10 \text { years by } 10 \% \text { ). } \\
\text { 4. Additional production of Regional Drinking } \\
\text { Water Company by } 15 \% \text { in the seventh year. }\end{array}$ \\
\hline & $\begin{array}{c}\text { III } \\
\text { Complex } \\
\text { (Optimist) }\end{array}$ & $\begin{array}{l}\text { 1. Land and forest rehabilitation by planting forest } \\
\text { crop in the brushwood area. } \\
\text { 2. Population growth by } 1.5 \% \text {. } \\
\text { 3. Leakage control by } 30 \% \text { (the first five year by } \\
15 \% \text {, and the following } 10 \text { years by } 15 \% \text { ). } \\
\text { 4. Additional production of Regional Drinking } \\
\text { Water Company by } 40 \% \text { in the seventh and } \\
\text { thirteenth year. }\end{array}$ \\
\hline
\end{tabular}

Land cover width changes will affect land economic value. Simple scenario increases land value for community obtained from products of harvests with different harvest time. If the moderate scenario is performed, community will have the profit obtained from long-term harvest time because of different types of plant and forest and land rehabilitation. And, if complex scenario is performed, community will have the profit from forest and land rehabilitation. However, this value is highly determined by land area width. 

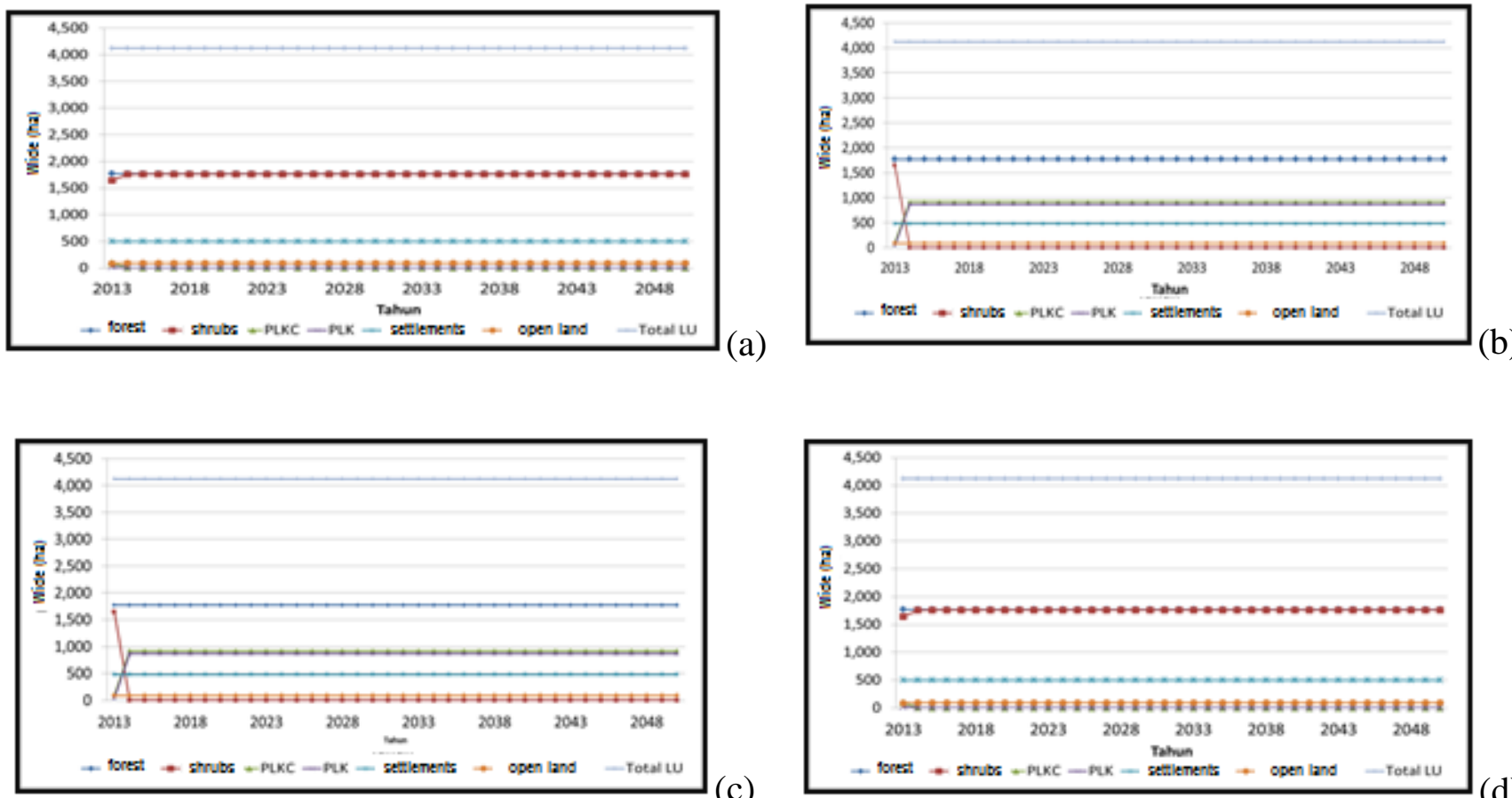

Information: (a) the conditions of existence; (b) Simple Scenario; (c) Moderate Scenario; (d) Complex Scenario

Figure 4. Ratio of land use changes rate for various scenarios

c. Stream Discharge Changes

Surface stream discharge in various land uses is presented in Figure 5 below.

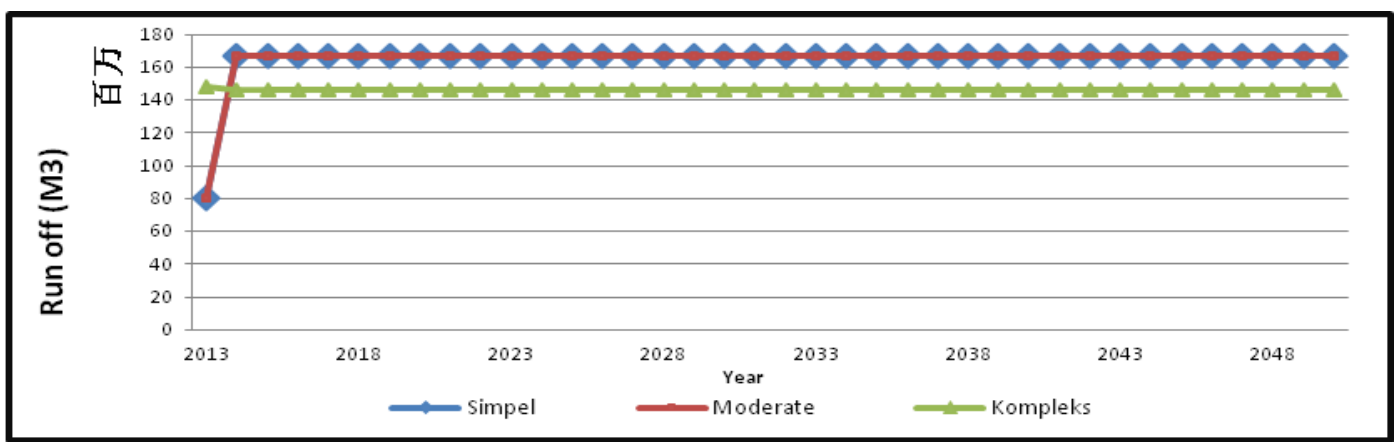

Figure 5. Surface stream discharge

Figure 5 shows that surface stream discharge is very low if moderate scenario is performed. The more extensive land built up by agroforestry concept, the lower discharge will be.

d. Water Needs

Assumption of water availability is calculated by dividing water production by water needs. It signifies that if water needs is higher with constant water production, ratio of water availability will be less than 1 . Accordingly, one unit of water will be consumed by more than one unit of water consumer. Ratio between water needs and water production is presented in Figure 6 below. 


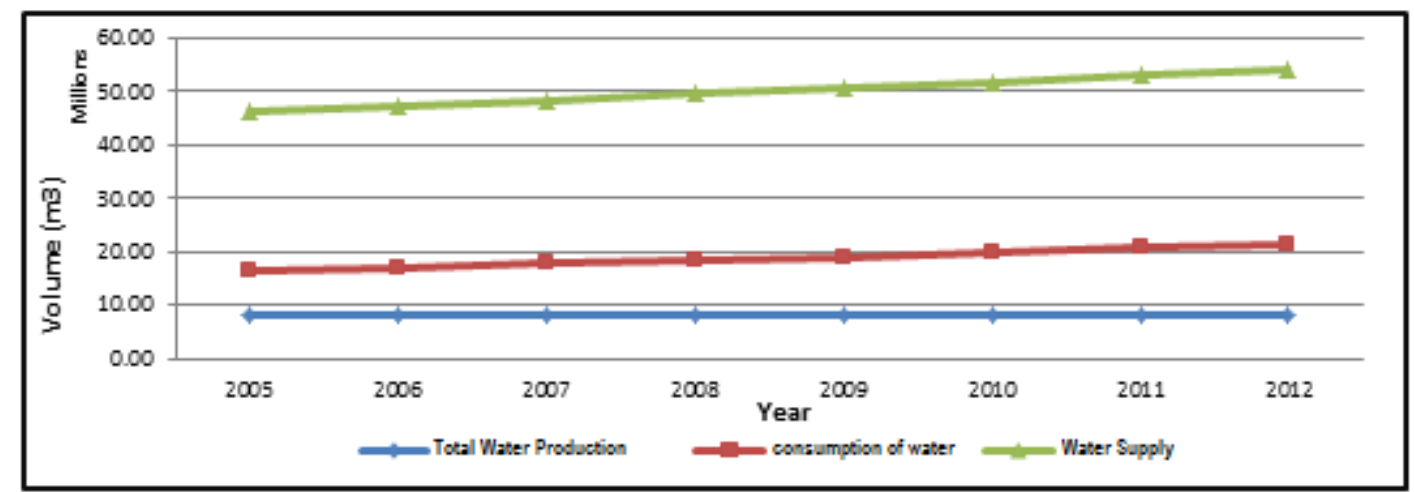

Figure 6. Total water availability, water production and water needs in Ambon City e. Water Balance

Table 6 shows that by performing Simple scenario, population growth is expected to increase by $2 \% / y e a r$ in which Regional Drinking Water Company shall control water production leakage up to $10 \%$ which is realized in steps along with community effort to utilize $100 \%$ water from rain, river, and ground water or purchased water. In moderate scenario, population growth control shall reach $2 \%$, water production leakage control performed by Regional Drinking Water Company shall reach $15 \%$, and community effort shall be $100 \%$ to obtain water from rain, river, ground water, or purchased water. Complex scenario is performed in an effort to control population growth up to $1.5 \%$ and to push water production leakage down up to $40 \%$ and to improve community effort in getting water up to $100 \%$ from rain, ground water, river or purchased water (deficiency in water production is fulfilled by Regional Drinking Water Company and Dream Sukses Airindo, Ltd.). Ratio between water consumption and production which is available in the watershed is presented in Figure 7 below. 


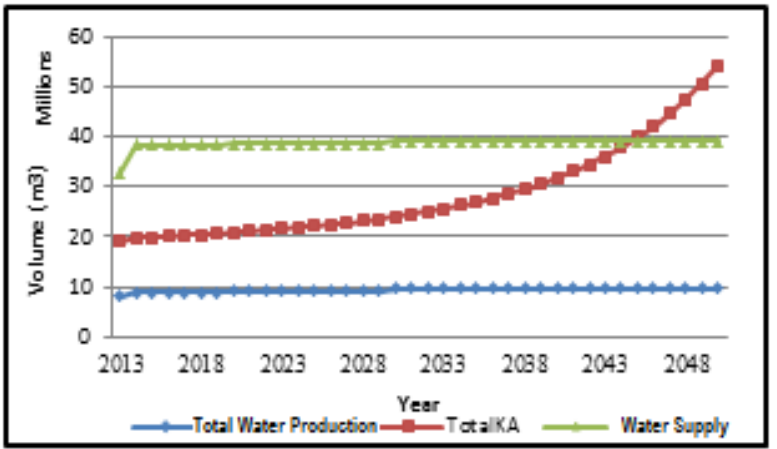

(a) Simpel Condition

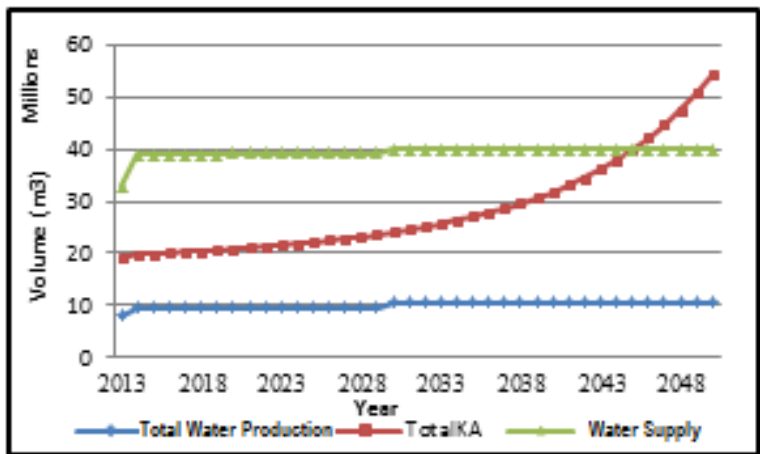

(b) Moderate Condition

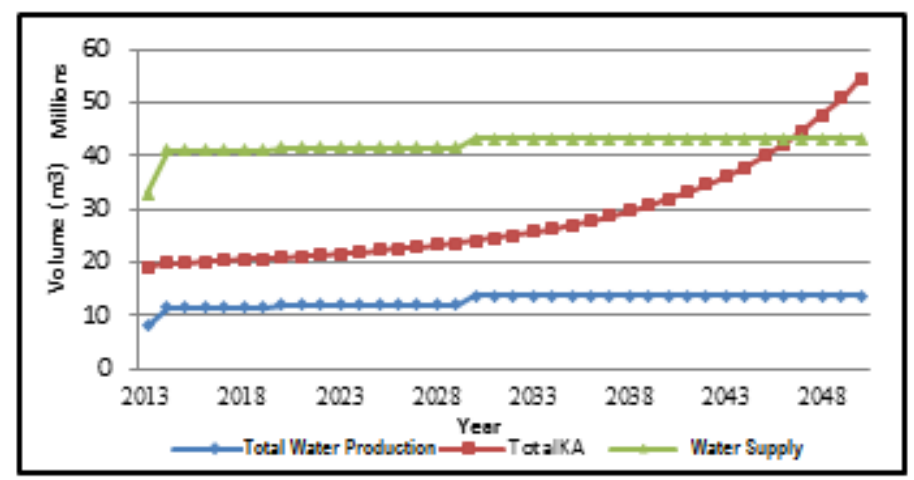

(c) Complex Condition

Figure 7. Simulation of water needs, water production and water availability

Based on Figure 7, complex scenario is able to maintain water availability in the river stream for water needs compliance until 2045 with water availability in the river by 43 million $\mathrm{m}^{3}$. However, water availability in the river can be utilized until 2045 by 39 million $\mathrm{m}^{3}$ if simple scenario is performed and by 41 million $\mathrm{m}^{3}$ for moderate scenario. According to the explanation above, it is suggested that watershed management shall be able to support water availability in Ambon City whereas, to increase community income, moderate scenario shall be the best logic scenario.

\section{Conclusion and Suggestion}

\subsection{Conclusion}

Based on the discussion above, some conclusions can be made as follows:

1. Watershed multidimensional sustainability status in Ambon City by $50.97 \%$ indicates quite sustainable. Sensitive leverage factors that can affect this sustainability index are 13 maintainable and intervening factors.

2. The best watershed management model in Ambon City shall use moderate scenario by performing land and forest rehabilitation and intensification of farming through agroforestry system. 


\subsection{Suggestion}

1. It shall be prioritized an improvement for sustainability dimension for the less sustainable dimension, i.e. ecological dimension. Multidimensional index shall be controlled and improved since the sustainability level is easily changeable to be less sustainable status.

2. The Regional Drinking Water Company shall increase clean water supply for the community by considering either leakage factor or new wellspring.

3. The local government can take population control by having city planning for new residential area since the watershed of Ambon City has turned to be ruined in the headstream of Ambon City.

4. Sea water desalinization shall be conducted to fulfill water demand, or by conducting water sharing from other watershed in Ambon Island.

\section{References}

[BPS]. Badan Pusat Statistik Kota Ambon. (2007). Kota ambon dalam Angka Tahun 2008.

Asdak C. (2007). Hidrologi dan Pengelolaan Daerah Aliran Sungai, Cetakan keempat, Yogyakarta, Gadjah Mada University Press.

Defra Making Space for Water. (2004). Taking forward a New Goverment Strategy for Flood and Coastal Erosion Risk Management in England. In: First Government Response to The Autumn 2004 Making Spacee for Water Exercse. [Online] Available: www.defra.gov.uk/environment.water/quality/nitrate.

Fauzi A., \& Anna Z. (2005). Pemodelan Sumberdaya Perikanan dan Kelautan. Untuk Analisis Kebijakan. Jakarta, Gramedia.

Kartodiharjo, H., \& Jhamtani, H (2006). Politik Lingkungan dan Kekuasaan di Indonesia. Cetakan Pertama. Equinox Publishing Indonesia. Jakarta.

Li, Y., Zhao, S., Kunzhao, Xie, P., \& Fang, J. (2006). Land-Cover Changes In An Urban Lake Watershed In A Mega-City, Central China. Environmental Monitoring and Assessment 115: 349-359. Springer.

Murtilaksono, K. (2009). Kebijakan Pengelolaan Sumber Daya Alam dan Lingkungan di Daerah Aliran Sungai, Makalah dibawakan pada Lokakarya RPJMN 2010 - 2014, Kementerian Negara Lingkungan Hidup RI.

Tuhumury, N. C. (2003). Analisis Pengaruh Perubahan Penggunaan Lahan Daerah Aliran Sungai Brantas Terhadap Keseimbangan Air Daerah Pesisir Sungai Brantas. Tesis Institut Pertanian Bogor. Tidak di publikasikan.

Wheater, H., \& Evans, E. (2009). Land Use, Water Management and Future Flood isk. Land Use Policy 26S (2009) S251-S264. [Online] Available: http://www.elsevier.com/locate/landusepol. Land Use Policy 26S (2009) S251-S264. 


\section{Copyright Disclaimer}

Copyright for this article is retained by the author(s), with first publication rights granted to the journal.

This is an open-access article distributed under the terms and conditions of the Creative Commons Attribution license (http://creativecommons.org/licenses/by/3.0/). 